\title{
Laine E. Doggett and Daniel E. O'Sullivan, eds., Founding Feminisms in Medieval Studies: Essays in Honor of E. Jane Burns (Woodbridge, Suffolk: D.S. Brewer, 2016). 280pp. Hardcover $\$ 126.00$.
}

This rich and suggestive volume of essays in honor of E. Jane Burns, the eminent and prolific feminist medievalist French scholar, wears Burns' illustrious colours with considerable aplomb. Edited by two scholars who know Burns well, and including essays by fourteen medievalist French literary scholars and historians, Founding Feminisms in Medieval Studies explores the Mongol silk trade, the early illustrated manuscripts of Marguerite de Navarre, Saint Anne's reading habits, and the Timbuktu effect, all with a pleasure and verve rightly celebrating Burns' own eclectic, playful, and magisterial body of work.

The collection is framed by a summary of Burns' contributions and a consideration of future directions for medieval studies, as well as an afterword by the one scholar of English literature in the collection, Elizabeth Robertson. Its essays are gathered into four bundles reflective of Burns' own interests: "Debating Gender," "Sartorial Bodies," "Mapping Margins," and "Female Authority: Networks and Influence." As Robertson suggests in her reflections at the end of the volume, these essays should allay the fears of any who think that historical women and their material conditions might have fallen by the wayside in medieval studies. The essays in Founding Feminisms are both rich in material detail—book history, manuscript provenance, illustrations, archival discoveries - and sophisticated in their readings of women's kinship networks, political alliances, reading and devotional practices, and cultural border-crossings. Considering both women's own texts and the portrayals and uses of women (and trans) figures in medieval French literatures, Founding Feminisms reveals the value and potential of such synthesizing work.

Matilda Tomaryn Bruckner's opening essay yields a central metaphor for the collection in its study of Jean d'Arras's $14^{\text {th }}$ century Melusine ou la noble histoire de Lusignan. The legend of Melusine, a woman who is part-human, part-animal, part divine, "stands as a pointer to the way humans cross boundaries" (28) and invites a reversal of "the clerical tradition's negative reading of Eve" (30), while it playfully, as Bruckner notes, forces its readers to "y penser et soy esmerveillier" ("to consider it and be amazed") (30). Kristin L. Burr's study of the $13^{\text {th }}$ century Roman de Silence likewise notes how the ambivalent narrator leaves the tale's heroine open to provocative debate. Daniel O'Sullivan, in turn, studies the Provençal male troubadour and female troubairitz, as the troubadour, like his Petrarchan descendent, depends upon the lady's disdain, while the female singers "are unwilling to remain rhetorical human shields" (60). Like Rosalind Smith's work on $16^{\text {th }}$ century English women sonneteers, O'Sullivan suggests that the empowering frustration of the male troubadour is proven fragile when the lady talks back. Lisa Perfetti also provides helpful casestudies on teaching the fabliaux to reveal their similar diversity of gender politics.

In the "Sartorial Bodies" section, Madline H. Caviness' impressive essay 
on "Hats and Veils" considers the complex and variable meanings of veils, wimples, hoods, and hats in depictions of wives, maidens, prostitutes, widows, Jews, nuns, and criminals. Surveying medieval Jewish codexes, the German Sachsenspiegel and art in manuscripts and stained glass, Caviness notes the cultural judgements implied by sartorial prescription and choice in medieval Europe. She provides copious evidence that "every time a dress code is imposed, abandoned, or changed it is worth asking whose agenda it advances, and whether it was negotiated by the wearers" (95). SarahGrace Heller turns the question back on men in her study of vestimentary allegories in the $13^{\text {th }}$ century works of Baudouin de Condé. She argues suggestively that these allegorical poems on the manteau and the gardecors encourage noblemen to put on loyalty and generosity to prove their masculinity. Ruth Mazo Karras and Tom Linkinen explore whether clothing (literally) makes the man in the case of John/Eleanor Rykener, the medieval Londoner accused and convicted of sodomy, cross-dressing, and prostitution for what we might now call a transgendered history. Karrass and Linkinen consider this complex case of both sartorial and sexual "swerving," a term Stephen Greenblatt would recognize.

Part III, “Mapping Margins,” includes Laine E. Doggett's rich account of maidens as healers in old French medieval courtly narratives. Unlike Wendy Wall's groundbreaking analysis of gendered household medicine (Staging Domesticity, 2002), Doggett focuses on the battlefield wound. Like Keith Thomas, Doggett attempts here to tease out the tensions between spiritual healing, natural knowledge, and magic, noting the frequent collapse of these categories in the hands of the noble maidenly healer. Sharon Kinoshita's fascinatingly wide-ranging essay "Silk in the Age of Marco Polo" examines Le Devisement du monde, written by Polo and Rustichello of Pisa, as Le Devisement reflects on the globalization of, and created by, the silk trade, from China and the Mongol empire to Mosul, Cathay, Venice, and Genoa. Helen Solterer pushes one step further out in her intelligent, detailed consideration of the curious figure of a Muslim protagonist in Honorat Bovet's $13^{\text {th }}$ century $A p$ paricion Maistre Jean de Meun. Solterer argues that this noble Saracen, "aussy noi comme charbon" ("as black as coal”) (153), both enables and disguises Bovet's critique of French decadence and internecine squabbling in what she calls "the Timbuktu effect."

The last section on female authorial networks pulls together beautifully illustrated examples of literary women's alliances in thirteenth- to fifteenth-century France. Cynthia J. Brown, Roberta L. Krueger, and Nancy Freeman Regalado all explore, with admirable precision and deft analysis, manuscripts revealing in word and art the reading and writing cultures which connected Christine de Pisan, Marguerite de Navarre, Anne de Bretagne, and Anne de France. Rasmussen's fascinating study of the fat books and healthy babies in depictions of St. Anne's Holy Family further connects both saintliness and kinship at the heart of literary medieval womanhood.

A rich set of materials, in every sense, and many suggestive lines of inquiry 
make this collection a worthy sign that St. Jane has given medieval feminist history and literary study much to be thankful for.

Elizabeth Hodgson

University of British Columbia

\section{William J. Bulman and Robert G. Ingram, eds., God in the Enlightenment (Oxford: Oxford University Press, 2016). 322pp. Hardcover $\$ 99.00$.}

This important collection of essays aims to address an irksome topic from an intriguing perspective, one that, so the editors hope, might help to heal the unfortunate impasse in the current debate between "liberals" and "communitarians" over the virtues or vices of the so-called Enlightenment project. The volume's main target is the well-known genealogy of the Enlightenment famously furnished by D'Alambert, who painted the Renaissance as preparing the ground for the Reformation which, in turn, made the Scientific Revolution possible. It was thus, according to this view, that the seventeenth century began the relentless destruction of what eighteenth-century philosophes would refer to as "the system," a quaint euphemism for Aristotelianism and the way in which Christian apologists had chosen to deploy it. Those who accept this view usually define the Enlightenment, to quote one of its most eloquent modern exponents, as "the broadly secular, experimental, individualistic, and progressive intellectual world ... in which the old and apparently unassailable forms of association, of belief and tradition, which had for centuries divided human beings into mutually suspicious and often brutally homicidal groups, were slowly and painfully, but irreversibly, abandoned" (Anthony Pagden, The Enlightenment and Why it Still Matters, 2013).

Like all neat historical explanations, this one can be readily questioned. The Renaissance and the Reformation did not inevitably lead to secularism. Indeed, the seventeenth century was an intensely religious age during which the materialism of a Hobbes or the monism of a Spinoza weighed light against the overwhelming mass of theologians and preachers who were almost solely responsible for popular instruction. Even in the eighteenth century, the increasing prestige and influence of the culture of the Enlightenment owed a great deal to the wide channels of international diffusion that it had acquired among the educated elites but which rarely reached the rest of the population. It is easy to forget that the vast majority of people in eighteenth-century Europe still lived in economically self-contained regional units with their own laws and institutions, that Voltaire and Bolingbroke were the contemporaries of Wesley and St Paul of the Cross, and that Gibbon and Adam Smith composed their great works at the same time as St Benedict Joseph Labre led the life of a medieval ascetic and widely admired miracle worker.

All the essays in this collection tap various aspects of this strangely neg- 